\title{
The Organization of African Unity (OAU): A Revisit
}

\author{
Esekumemu Victor Clark, D.Phil (Vienna) \\ Department of Political ScienceDelta State University,Abraka, Nigeria
}

\begin{abstract}
The OAU came into being in May 25th, 1963, when the then independent states of Africa met in Addis-Ababa, Ethiopia, to put in place the largest continent diplomatic organization. From the onset the Organization was battered and faced aggressive realpolitik of the major powers in their Cold War geopolitical calculations. Indeed, the brinkmanship game of the competitive interactional relations undermined the evolution of the OAU on issues such as decolonization, development, economic integration and political stability. Since the transition of the OAU to African Union (AU) in 2002, the Union is still marred by a series of problems, including economic, civil conflicts and wars. As such the paper recommends appropriate strategies to retool the myriad of problems and issues in order to strengthen the AU and to put the continent on a sound footing.
\end{abstract}

\section{INTRODUCTION}

The Organization of African Unity (OAU) now the African Union (AU) since 2002, was founded in May 25th, 1963, at Addis Ababa, Ethiopia, by the then 25 independent states of Africa. Indeed, the Organization was established at a pretty difficult moment in African political and diplomatic history. It is the largest continental Organization in the world, today with fifty four (54) member states. Infact, it was a major diplomatic step taken by the then African leaders to navigate the continent from the brinkmanship game played by the major powers and also to promote and secure Africa's interests in the diplomatic universe (Clark, 1991; Rubin and Weinstein, 1977; Ojo, et al 1985, and Sesaay, et al 1984).

\section{CONCEPTUAL CLARIFICATION}

The issue of war has been a worrisome case to humankind and also how to prevent future wars. After the end of the Thirty years war amongst the then European communities in 1648 which led to the Westphalian Treaty and also the beginning of the modern state-system in Europe. From the Westphalian state-system to Versailles, the international system was characterized by realpolitik, secret diplomacy and imposition of straitjacket on the weaker members of societies by the stronger ones. Indeed, imperialism and colonialism were the hallmarks of the international system. With the conclusion of the First World War (WWI), statesmen, among others, gathered in Paris, France to sign the peace treaties, including the Versailles Treaty in June, 20, 1919, where the idealist U.S. President Woodrow Wilson, tabled his Fourteen (14) points. He wrote "Open covenants of peace, openly arrived at", and the abolition of secret diplomacy. Among others, in the Fourteen Points, he argued for the idea of open diplomacy, to replace secret diplomacy that was the norms and practices then by nation-states in the international system. Thus, the art of secret diplomacy practice by kings in their Courts without the involvement of their citizens on important national affairs had severally plugged their nations into wars without the concert of their people. President Wilson stressed the need for a multilateral diplomacy, such as an international organization, where representatives of every member state of the organization will deliberate on world issues such as peace, trade and commerce (Khan, 2007; Clark, 1991; Archer, 1983; Mbali, 2013).

Hence, one of the outcomes of the Paris Peace Conference was the establishment of the league of Nations on January, 10, 1920. One major role that the league of Nations was to play the maintenance of international peace and security among the comity of nations. However, the US was not a member state of the Organization, because of America's domestic politics, including her geopolitical calculations. The US Congress noted that the outcomes of the Treaties, including the Vesailles Treaty, did not reflect and represent American interests. As such, when the European dictators, like Hilter of Nazi-Germany, Mussolimi of Fascist Italy and Stalin's communist Soviet Union as well as Japan's militarism in Asia, challenged and undermined the existing status-quo-ante in the international system, but the league of Nations was too weak to checkmate their actions around the world, including Africa. Nevertheless, at the Paris Peace Conference the power politics or the geopolitical considerations exhibited by the victorious Allied, the US, UK, France and Italy undermined proper articulation of the peace process. For instance, the defeated powers such as Germany, Turkey and Bulgaria their views were not well represented at the Paris Peace Conference. The idealist principles of the U.S. President Wilson were torpordoned by realist positions of President Clemenceau of France and President Orlando of Italy (Khann, 2007). From the onset the league of Nations, an international organization put in place was weak and could not perform its function of maintenance of peace and security in the global society. The league of Nations was the first international organization created for peacebuilding, but was compounded by the brinkmanship 
game of the major countries, their national interests became of paramount importance at the detriment of world peace (Clark, 1991).

Meanwhile, international organizations and institutions according to the idealists where nation states were to work for conflict resolution and management as well as promoting cooperation and development for the benefit of mankind. Indeed, Immanuel Kant, the German philosopher of the eighteenth century, stressed that politics should be placed at the service of morality to help promote peace in a complex world. That international anarchy could be controlled or stopped if nations act collectively to defuse conflict. He stipulated that if nations work and put concrete methods in place to avoid war, there would be peace, cooperation and trade that would dovetail into prosperity, among the comity of nations. Thus, the idealists noted that through the strengthening of international organizations and institutions such as the UN, AU, ECOWAS (Economic Community of West African States), AFDB (African Development Bank), WTO (World Trade Organization), IMF (International Monetary Fund) and World Bank (International Bank for Reconstruction and Development) would lead to peace, security, cooperation, macroeconomic stability and the promotion of the development of international law (Mingst, 2004; Mbah, 2013; Clark, 1991; Morgenthau, 2005; Kissinger, 1994).

While, Realism is not in full support of international organizations and institutions being given preeminent role in international relations, the realists argue that the state should be the centrality of international politics. Thus far, states because of their national interests are undermining the activities of international organizations and institutions. For instance, in the UN especially in the Security Council the five permanent members with their veto power had and are still undermining the Organization's working and operating because of their national interests. During the Cold War the two major protagonists, the US and USSR, including their allies in their brinkmanship policy drive contributed to insecurity around the world (Owoeye, 1993). The US invaded Iraq under the pretext of weapons of mass destruction in 2005, while Russia invaded Georgia 2010, under gist of protecting Russian citizens, i.e. self-determination. One might argue that both Americans and Russians behaviour were a violation of the UN Charter, thus, their actions undermined the strengthening of international law and international relations.

\section{FORMATION OF THE OAU}

The grand child of Pan-Africanism, the Organization of African Unity celebrated its Golden Jubilee on 25, May, 2013, in Addis-Ababa, Africa's diplomatic capital. In the early 1960's the way to African political development was conceptualized by Africans, hijacked by two movements. The Casblanca Group led by Ghana and Egypt advocated for a radical approach to Africa's unity and development. While, the conservative Monrovia Group led by Nigeria and Liberia emphasized the need for a piecemeal approach to Africa's socioeconomic and political development. Both groups, respectively, seek the leadership of Africa, as well as which directions to lead the continent in terms of socioeconomic and politically. Certainly, Africa was in a dilemma, as the both groups tussled over the politics, it led to mistrust, misunderstanding and colouration of perceptions between the Casblanca and Monrovia groups. The problem then was which ideologies to follow, capitalism or socialism? Consequently, the struggled for the heart of Africa, by the two groups had gross ramifications, left ripped effects on the continent (Clark, 1991).

The two opponent's views as articulated by both the Prime Minister Sir Abubakar Tafawa Balewa of Nigeria and President Kwame Nkrumah of Ghana, respectively, in order to boosted their groups' arguments during the process of endeavouring to put in place the OAU.

Some of us have suggested that African Unity should be achieved by political fusion of the different states in Africa; some of us felt that African unity could be achieved by taking practical steps in economic, educational, scientific, and cultural cooperation and by trying first to get Africans to understanding themselves before embarking on the more complicated and more difficult arrangement of political union. My country stands for the practical approach to the unity of the African continent ${ }^{1}$. (Late Sir Abubakar Tafawa Balewa, Prime Minister of Nigeria. Addis-Ababa Conference, 22-25, May, 1963).

This view takes no account of the impact of external pressures. No does it take cognizance of the danger that delay can deepen our isolation and exclusiveness; that it can enlarge our differences and set us drifting further apart into the net of neo-colonialism, so that union will become nothing but a fading hope and the great design of Africa's full redemption will be lost, perhaps forever ${ }^{2}$. (Late Dr. Kwame Nkrumah, President of Ghana, Addis-Ababa Conference, 22-25 May, 1963). The development in the Congo in the early 1960s informed both the Casablanca and the Monrovia groups to close rank and meddle fences as the unity of Africa become of paramount importance. As the newly independent state of Congo was thrown into political crisis fueled by both internal and external forces. For instance, the Congolese Prime Minister Patrick Lumumba decided to pursue an independent foreign policy from Belgium the former colonial power, but Brussels disagreed with the Congolese government. The West saw him as a socialist oriented and also bended on dismantling their interests in the Congo. Thus, Belgium supported by other Western powers, including the United States encouraged civil conflict as well as a secessionist war in the province of Katanga (see among 
others, Calvocoresssc, 1986). The Western powers noted that Lumumba should not only be removed from power, but should be killed. They saw him as a threat to their national security interests in the Congo and Africa as a whole. Congo is very rich in raw materials, including strategic minerals. For example, the Uranium used to develop the first hydrogen bomb used against Japan by the United States during the Second World War (WWII) was procured from the Congo (see among others, Clark 1991; Clark, 2008).

One might argue that in terms of geopolitical calculations, the West was not ready or prepared to lose Congo to the Soviet's sphere of influence or control, per se. In the world of realpolitik, for them to keep Congo Prime Minister Patrick Lumumba was eliminated with the supports of Mobutu, among others. Thereafter they kept Mobotu in power to ensure that their strategic interests were protected in Africa. After the demise of the Cold War in 1989, most of the dictators in Africa, including President Mobutu of Zaire their role became irrelevant in international politics, they lost their support base with the superpowers (hyperpowers), and subsequently several of them collapsed (Clark, 2008. Huntington, 1991). In any case, the policy of the brinkmanship of the major powers in the Congo pushed African leaders to take decisive step in multilateral

1,2, adapted from Leslie Rubin and Brian Weisestein, (1977) Introduction to African Politics: A Continental Approach, New York: Praeges Publishers, Pp. 245-246

diplomacy in order to avoid the

dismemberment of the continent. The process led to the establishment of the Organization of African Unity in 1963. Clark (1991:95) wrote

The statecraft which led to the compromise and understanding, which culminated in the inception of the OAU was a milestone in global diplomacy.

Again, on $25^{\text {th }}$ May 1988, the Organization of African Unity, marked its Silver Jubilee, at a difficult period of the Cold War. As the International Herald Tribune (Paris), on 26th April 1988, chroncled:

The first continental Organization of its kind in the world.

\section{Evolution of the OAU}

The purposes of the Organization of African Unity (OAU) were apparently well listed in Article. 2(1) of the Charter: These include

(a) to promote the unity and solidarity of the African states;

(b) to coordinate and intensify their cooperation and efforts in achieving a better life for the people of Africa.

(c) to defend their sovereignty, their territorial integrity and independence.

(d) to eradicate all forms of colonialism from Africa; and

(e) to promote international cooperation, having due regard to the Charter of the United Nations and the Universal Declaration of Human Rights.

According to Clark (1991:96),

The Organization since its inception in 1963, has made a significant contribution in the development of both international and national laws, in order to maintain and contribute to peace, security and stability in the global system. The Charter of the Organization of African Unity (OAU), stipulates in its purposes and its principles on how to achieve its aims, in order to create a better society for freedom, equality, justice, respect, peace, security, stability, etc., in the African continent.

Thus, Article II (1) of the Charter of the OAU as provided for in the purposes, in 1(a) "to promote the unity and solidarity of the African states". African states gaining their political freedom, they have to be mindful of the competitive international relations that was marked by the brinkmanship game of the Cold War. As such the newly independent states of Africa were concerned to promote their unity and solidarity so as to avoid the continent of Africa being used again as a guinea pig of the unfolding Cold War between the superpowers (US and USSR). The past colonial experience including the Partition in 1885, in Berlin, Germany exposed the continent of Africa to the poker politics and games of the major powers, with dire consequences which are still rotating around the development and progress.

Furthermore, under Art II(b) it puts emphasized on cooperation 'to co-ordinate and intensify' their collaboration in order to create conducive environment where the people would participate fully in economic process that would lead to development and progress. It is also provided in Art II(c) 'to defend their sovereignty, their territorial integrity and independence'. Hence, it was critical for the states in Africa then, when they formally gained political freedom to protect their sovereignty and national interests from external policies that might throw them into crisis and disintegration. Again, provisions were made in Art II(d) 'all forms of colonialism', including all those territories still under foreign domination should be set free from colonial straitjacket. At the onset of the OAU was seriously involved in the decolonialization fight in order to free the remaining colonial vestiges in Africa. The Organization also worked tirelessly to see that the apartheid system is dismantled from both South Africa and Namibia, respectively. 
Nevertheless, the OAU also work pretty hard to make sure that the continent of Africa, do not become a play ground of the Cold War between the protagonists. For instance, in Angola, the brinkmanship game played by the superpowers in the final phase of that country's independence was dangerous. In April 1974, the colonial power, Portugal pulled out of Angola, thus a vacuum was created and immediately that vacuum was filled by the hyperpowers, the Soviet Union and the United States. Among others, the both powers supported and championed the cause of the different nationalist movements, such as the Movimento Popular da Libertacao de Angola (MPLA) and Uniao National para a Independēncia Total de Angola (UNITA), so that their surrogates will fill the vacuum in Lunda left by Portugal. The United States' administration under President Reagan in order to ensure that America's interests in that region will not be undermined as such he proclaimed the Reagan Doctrine. The Doctrine is meant to destabilize Pro-Moscow communist regimes in Southern African and elsewhere (Clark, 1991; McFaul 1989/90). Hence, the OAU was very keen to see that the power tussled among the major powers to advance their geopolitical calculations in Africa was at least avoided. In the final analysis, the OAU was very successful in its effort in the decolonialization process and the dismantling of apartheid system in South Africa and Namibia.

In the OAU Charter it is provided for in Article II (e) 'to promoted international cooperation, having due regard to the Charter of the United Nations and the Universal Declaration of Human Rights'. The OAU had strengthened and contributed to development of the UN in accordance to the Charter of the UN and the Universal Declaration of Human Rights, Per se. The OAU has strongly supported multilateral diplomacy such as its member states contributing to peacekeeping and peace-building, among others, under the UN authority, to ensure peace, security, stability, the development and progress in the world. In international relations, the OAU had bilateral relations with several regional organizations and movement such as the commonwealth, EU, ACP, and Non-Aligned Movement (NAM), through its member states.

Meanwhile, the OAU in 1980 put in place the Lagos Plan of Action (LPA) and the Final Act of Lagos (FAL) in 1981, to enable Africa to claim her development plan back and also to participate fully in the international division of labour (see among others, Adedeji 1985; Ake, 1996; Clark, 2008; Teriba 1991, Asante 1997). The LPA was an OAU strategy to move and strengthen Africa in the global economy. However, this effort made by the OAU to refocus and reposition African economy met with serious oppositions from the international community, including the Bretton Woods Institutions.

In 1981 the OAU put in place the African Charter on Human and Peoples' Rights (Banjul Charter) to address issues of abuses of human rights in Africa. The step taken by the Organization was to contribute to the progressive development, promotion and protection of human rights. One might argue that the Banjul Charter was the first human rights legal instrument in the world to incorporate the right to development in Articles 22 and 23. As provided for in Article 22: the right to development and in Article 23: the right to enjoy a favourable air in the process of development. Infact, development is essential and imperative, in order for society to improve its standard of living. Hence, the Preamble of the Banjul Charter noted

That it is henceforth essential to pay particular attention to the right to development and that civil and political rights cannot be dissociated from economic, social, and cultural rights in their conception as well as universality and that the satisfaction of economic, social and cultural rights is a guarantee for the enjoyment of civil and political rights.

In 1989, the African Commission on Human and Peoples' Rights was put in place, where it was ratified by two-thirds of the states in Africa.

Meanwhile, the Organization of African Unity was engaged in preventive diplomacy. It made efforts in settling, resolving and managing conflicts in the continent of Africa. The Organization was involved in settling both intrastate and interstate crises such as in Ethiopia, Sudan, Zaire, Angola and Nigeria. In preventive diplomacy the OAU used its peace-building methods, such as diplomacy, mediation, conciliation and peacekeeping to endeavour to find peaceful solutions to the various crises in Africa. In 1981, for instance, OAU peacekeeping force was sent to maintain peace in Chad during a civil conflict, when the power elites were engaged in power struggled to control and rule that fragile country. Indeed, the Organization was pretty instrumental in the used of its mechanism of preventive diplomacy to prevent the former colonial borders being changed by force by the newly independent states in the continent of Africa, in order to avoid disintegration. Clark (2008:115) wrote:

True, the OAU's recognition of the colonial boundaries legitimized the concept of 'Uti possideties', which established the principle that those former borders drawn at the time of the partition of the continent should not be revoked

In 2002, the African leaders met in Durban, in South Africa, where the OAU was transformed into the African Union (AU). During the OAU's silver jubilee in 1989, I wrote elsewhere, 'Pan-Africanism' (1989), that the OAU should be restructured among others, that a permanent security council, modeled after the United Nations Security Council should be established in the OAU. This suggestion was made even before the leaders of the OAU even conceived the idea of the transition of the OAU to AU. However, the AU is working pretty 
hard to see that its New Partnership for Africa's Development (NEPAD), among others, is realized, so as to boost Africa in the global economy.

\section{Geopolitics in Africa}

Geopolitically, the continent of Africa had and is still being undermined by the policies pursued by the major powers. For instance, the North Atlantic Treaty Organization (NATO) military intervention in Libya that led subsequently to the removal of Col. Mummar Ghaddafi had negative effects on Africa. However, Libya was not secured and stabilized by the Organization's action, but it led to insecurity in that country. The security and stability, peace, development and prosperity that Col. Ghaddafi provided for Libyans and others were erorred by NATO's actions in the civil conflict. Hence, Africa is facing geopolitical problems caused by the spread of Islamic Jihadists such as ISIL and Boko Haram in several countries. If Col. Ghaddafi was life and in control of Libya, ISIL will never be tolerated to have a foothold in that country. Indeed, most Islamic terrorist groups, including the Boko Haram, in Africa are now affiliated to ISIL (Clark, 2011). The departure of Col. Ghaddaffi from power led to a vicious circle that led to the spread of arms to the hands or Islamic terrorists of other insurgent groups in Africa. Those arms that are being used by terrorists, among others, to pursue their evil ambitions, including killings and destruction of properties in several countries in Africa most came from Libya. For example, the Boko Haram terrorists in Nigeria have killed several hundreds of people, destroyed properties, churches and Mosques. For several years, the Nigerian security forces are battling the Boko Haram sect in the North East of Nigeria. The Boko Haram terrorists have also extended their threatre of operations and attacks to other Lake Chad Basin countries such as Cameroun, Niger and Chad with the lost of lives and materials. Today, in Nigeria another group has emerged known as Fulani Herdsmen causing havoc in every part of the country. This new group who posed as cattle rearers are killing people, destroying farms, villages as well as armed robbers. They move around with dangerous arms, including AK 47 riffles, which they used to cause robbering etc. The Fulani Herdsmen are members of the Boko Haram sect, masquerading as Fulani Herdsmen.

One might argue that most of the arms being used by those Islamic groups in Sub-Saharan Africa are from Libya. The geostrategic interests of NATO countries was mainly to secure and control Libya's oil fields, which Col. Ghaddafi deprived some of them when he came to power in 1969. In 1969 when the young and marcurial Col. Ghaddafi came to power he nationalized most of the western oil multinational corporations and military bases operating in Libya then. This is one of the fundamental reasons why the West disliked Ghaddafi (see among others, Clark, 2011).

Thus, the game of geopolitical calculations among the major powers, such as the US, France, UK and China for Africa's raw materials, including strategic minerals had led to serious competition with profound consequences. Infact we saw the rivalry over South Sudan's oil between China and the U.S. Several lands in Africa are being crabbed by the extraAfrican powers. Thus, NATO countries, led by the US created an AFRICOM (African Command) with its headquarters based in Germany to oversee their interests in the continent of Africa. Asian powers like India, Asian Tigers, among others, have also joined the race to secure their economic, trade and commerce interests in several countries in Africa. Now all sorts of substandard manufactured goods, including fake drugs are flooding the markets in Africa from the rest of the world. The policies of the extraAfrican powers are having severe effects on politics, economics, security, stability, peace, health, development and environment.

Among others, the geopolitics in Ukraine which has led to the contest between the West and Russia over the political direction of that country in the comity of nations. It has led to the manipulation of oil prices by the West in the international market with dire consequences for oil producing developing countries. For instance, in Africa those oil producing countries such as Nigeria and Angola with the oil price downturn as a fallout of global oil gluh are facing severe budgeting problems. Infact, prices of several manufactured goods and other commodities have rose astronomically in those countries. In Nigeria inflation is now running at double digits $11 \%$ in June 2016.

\section{CONCLUSION AND RECOMMENDATIONS}

The Organization of African Unity (OAU) was created in 26th May, 1963, in Ababa, Ethiopia. Indeed, the spirit of Pan-Africanism took precedent over the different political thinking and directions that were promoted by the different factions of Pan-Africanism, such as the radical Casablanca and conservative Monrovia groups came together to reposition themselves to the cause of African Unity. That single act prevented the disintegration of the continent of Africa by the brinkmanship game of the major powers as was demonstrated in Congo.

Separately, over four decades of its existence the OAU through its decolonialization, peacebuilding, peacekeeping, coherent foreign policy, etc, was able to position Africa among the comity of nations. However, in 2002 in Durban in South Africa leaders of Africa made a u-turn to transform the OAU to AU (African Union) to put strong emphasis on economic matters as the political decolonialization was successfully completed. 


\section{RECOMMENDATIONS}

The African Union should put a strategy in place to combat the spread of Islamic Jihadists, among others, in Africa. Hence, the Union should establish an anti-terrorist force to tackle the menances of terrorism in the continent. The then Organization of African Unity (OAU) Anti-terrorist clause should be activated, before it is too late, a conversion policy, such as political, diplomatic and military should be adopted to combat terrorism in every part of Africa. For example, the Lake Chad Basin states which comprises Nigeria, Chad Cameroun and Niger had created the Lake Chad Basin military pact to fight the Boko Haram's threats in the Lake Chad area.

The African Union (AU) should endeavour to strengthen and promote good governance in every country in the African continent. Leaders and their governments should promote democratic norms, values and practices that will ensure free and fair election as well as the protection and promotion of human rights in Africa. Thus, the African charter on Human and Peoples' Rights (Bangul Charter) should be strengthen in order to avoid abuses of human rights. Infact, good governance will dovetail in security, peace, stability and prosperity in Africa.

Indeed, the African Union should work harder to diversify the African economy to put emphasis on the production of manufactured goods. Thus also the Union should encourage economic integration among its member countries, as such the African Economic Community Treaty signed in 1991 in Abuja, Nigeria should be reactivated in order to boost the African economy. The Union should reposition its New Partnership for Africa's Development (NEPAD) and revisit the Lagos Plan of Action (LPA) so as to strengthen and enable the African economy to integrate and participate fully in the international division of labour. Hence, with a strong economic bloc such as the African Economic Community (AEC) in place, Africa can speak with one voice in international trade talks, such as the WTOs. Doha ongoing trade round negotiations. In the region industrialization should be given a top priority. The emphasis should now be focused on moving from the production of raw materials to production of secondary goods that would add more value to the regions exports at the international market. It would also reduce the dumping of substandard goods among others.

Certainly, energy is a big problem in Africa. Over 600 million Africans are without adequate power (CNBCA, May, 2016). African Union should put an energy policy in place to tackle the power situation. The continent of African is very rich in energy such as solar, hydrocarbon and winds which can be harnessed to tackle the power issue. Also environmental degradation is a major problem facing Africa, that would need the full cooperation of all countries in Africa to find a common solution. On the recently concluded Paris Earth Conference, Africa should endeavour to work with the rest of the world, so as to maximize her own interest among the comity of nations.

During the Libya Campaign by NATO Africa's sovereignty was violated, thus it was against the norms, rules and regulations governing international law and international relations. Indeed, the charters of the UN and AU were breached by the NATO'S operation against Libya. Now the AU must put in place a coherent foreign policy position to prevent any such occurance in the future.

\section{REFERENCES}

[1] Adedeji, A. (1985). The Monrovia Strategy and the Lagos Plan of Action: Five Years after, PP. 9-34, in Adebayo Adedeji and Timothy M. Shaw, eds, Economic Crisis in Africa: African Perspectives on Development Problems and potentials, Boulder: Lynee Riener Publishers.

[2] Adedeji, A., Teriba, O., Bugeribe, P. (1981). The Challenge of Africa Economic RecoveryandDevelopment, (eds), London: Frank Cass. (see all chapters).

[3] Archer, C. (1983). International Organization: Key Concepts in International Relations. London: George Allen and Unwin.

[4] Asante, S.K.B. (1997). Regionalism and Africa's Development: Expectations, RealityanChallenges. London: Longman.

[5] Calvocoressi, P. (1986). Independent Africa and the World. London: Longman.

[6] Clark, E.V. (1989). Pan Africanism, Vienna: Harambee. Vol. 3, Pp. 4-7.

[7] Clark, E.V. (1991). African International Relations: The Post - Cold War Era. Vienna, Development Publishers.

[8] Clark, E.V. (2008). A short Diplomatic History of the Cold War: An African Experience. Benin City, Allen Publications.

[9] Clark, V.E. (2011). Oil Diplomacy: the Impact on Democratic Governance. International Journal of Development Studies, Vol. 3, NO. 2. Pp 168-175.

[10] Huntington, S.P. (1991). The Third Wave Democratization in the Late Twentieth Century Norma: University of Oklahoma Press.

[11] Kharn, V.N. (2007). International Relations. New Delhi: Vikas Publishing House.

[12] Kissinger, H. (1994). Diplomacy. New York. Simon and Schuster. 
[13] Mbah, M.C.C. (2013). International Organizations and Institutions in World Affiars. Nimo: Rex Charles and Patrick.

[14] McFall, M. (1989/90). Rethinking the "Reagon Doctrine" in Angola. International Security. Vol. 14, No. 3, Pp. 99-135.

[15] Mingst, K.A. (2004). Essentials of Internaitonal Relations. New York: W.W.

Norton and Company

[16] Morgenthau, H.J. (2005). Politics Among Nations: The Struggle for Power and

Peace: New York: McGraw-Hill/Irwin.

[17] Ojo, O., Orwa, J.C. and Utete, B. (1985). African International Relations. London: Longman. (eds) see all chapters.

[18] Owoeye, J. (1993). Understanding the New World Order. Ibadan: College Press. Edited. See all chapters.

[19] Rubin, L. and Weisestein, B. (1977). Introduction to African Politics: A Continental Approach. New York: Praeges Publishers.

[20] Sesaay, A., Ojo, O. and Fasehun, O. (1984). The OAU After Twenty Years. Boulder: Westview Press (eds) see all chapters. 